\title{
Telling time in the Fourth Gospel
}

\author{
Jerome H Neyrey \& Eric Rowe \\ University of Notre Dame, Indiana (USA)
}

\begin{abstract}
When we begin the task of telling time in the Fourth Gospel, we bring something not found in any previous study, namely, a model of time articulated by cross-cultural anthropologists (Bordieu, in Pitt-Rivers 1963:55-72, Ayoade, in Wright 1984:71-89). As much as we admire Davies' study, she has no notes to her chapter on time nor any citations in her bibliography to indicate that she has any conversation partners, much less cultural experts, a deficit to be filled in this study. Learning to tell time entails three theoretical considerations: a definition of time, key classifications of it, and special attention to what the ancients meant by past, present and future. With these lenses we are prepared to do as thorough a study as we can on telling time in the Fourth Gospel. As we consider each classification, we will suggest a brief meaning of it from the experts on time, then present a body of Greco-Roman materials illustrative of the classification, and finally use it to gather and interpret data in John. Proving the native existence of these classifications for telling time in antiquity is essential for readers to have a background against which to compare their usage with that of the Fourth Gospel.
\end{abstract}

\section{INTRODUCTION: PROBLEM AND SOLUTION}

\subsection{The State of the Inquiry}

We are not the first to try to tell time in the Fourth Gospel. One finds, for example, the occasional article on particular hours (Walker 1960:69-73;

Salvoni 1963:236-241; Davies 1992:44-66). Likewise, consideration has been given to Johannine temporal markers (Brown 1966:517-518; Barret 1978:261262; Keener 2003:652-653). Only Margaret Davies moves beyond these data to consider systems of structuring time by using classifications such as history and eternity, duration, and past, present and future (Davies 1992:44-66). Her advance is facilitated by use of conventional, cultural classifications of time which serve as magnets to gather data in the gospel. But even here, only a beginning has been made (Busada 2003).

"Eric Rowe is a PhD student at the University of Notre Dame. 


\section{Telling time in the Fourth Gospel}

Many questions remain in regard to telling time in the Fourth Gospel. First, a full accounting should be given of calendrical time markers, of which the gospel is full, an indicator that telling time is important here. Second, interpreters must take into account the pervasive misunderstandings of Jesus's remarks on time by friends and foes alike. Why is it so hard to tell time? Third, many classifications of time are available to readers ancient and modern, such as before vs after; ordinary vs particular; sequence vs duration; eternal vs contingent. Use of these will not only surface still more data in John but contribute to a fulsome system of time. Culpepper (1983:54-75) called attention to some of these classifications: order/sequence, duration and frequency. His source is narratology, not the social sciences; hence, he notes some elements, but fails to recognize others. Much remains for a full telling of time.

\subsection{Why must this be done?}

Why conduct this inquiry? What benefit will it yield? What will it add to the current conversation? First, there is a considerable amount of data in the Fourth Gospel that has not been examined, namely the materials on time. In addition to merely cataloguing the traditional calendar markers, one must ask if Jesus discards them or reforms them. We will argue that knowledge of the classificatory systems of time in the Fourth Gospel is an integral element in the argument of that gospel as well as to a proper understanding of Jesus himself. It seems that John articulates a unique system of time which elevates Jesus's career and identity. For example, Jesus may come after John according to earthly chronology, but he was before John (1:15; 30), as an already existing being and as one who enjoys precedence. Similarly, Jesus says, "Before Abraham came into being I AM" (Jn 8:58), implying his existence even prior to that of Abraham, a different kind of existence. Jesus, it will be argued, does not fit into a time framework which applies to what is below and of this world? When all is said and done, we are also tempted to say that he is the Lord of Time, because he controls every hour of every day.

\subsection{Our plan and its parts}

When we begin the task of telling time in the Fourth Gospel, we bring something not found in any previous study, namely, a model of time articulated by cross-cultural anthropologists (Bordieu, in Pitt-Rivers 1963:5572; Ayoade, in Wright 1984:71-89). As much as we admire Davies's study, she has no notes to her chapter on time nor any citations in her bibliography to indicate that she has any conversation partners, much less cultural experts, a deficit to be filled in this study. Learning to tell time entails three theoretical 
considerations: a definition of time, key classifications of it, and special attention to what the ancients meant by past, present and future. With these lenses we are prepared to do as thorough a study as we can on telling time in the Fourth Gospel. As we consider each classification, we will suggest a brief meaning of it from the experts on time, then present a body of Greco-Roman materials illustrative of the classification, and finally use it to gather and interpret data in the gospel. Proving the native existence of these classifications for telling time in antiquity is essential for readers to have a background against which to compare their usage with that of the Fourth Gospel.

\section{TELLING TIME IN JOHN}

Like everyone else in the ancient world, the author of the Fourth Gospel could reckon time, that is, calendrical/chronological time (Leach 1966:134-135). ${ }^{1} \mathrm{He}$ tells of daybreak (Jn 18:28; $20: 1 ; 21: 4$ ) and that a typical day has twelve hours (Jn 11:9). In a day there is a sixth hour (Jn 4:6; 19:14), a seventh hour (Jn 4:52) and a tenth hour (Jn 1:39). For rhetorical purposes, he reckons exact calendar time, namely, that Lazarus was entombed for four days (Jn 11:17) or that Jesus enters Jerusalem six days before Passover (Jn 12:1); his resurrection appearances occur on the first day of the week (Jn 20:19, 20:26). Reckoning the meaning of a period of many years would seem to lack precision, but their numerousness rather than precision seems to be the point: the temple has been being built for 46 years ( $J n$ 2:20); the man at the pool was ill for 38 years (Jn 5:5); Jesus is acknowledged younger than 50 years old (Jn 8:57). The feast days mentioned are exact calendar dates widely known (Passover, Tabernacles, and Dedication). Sabbath plays a role in assessing Jesus's healings, for some traditions took the injunction to rest on the seventh day literally; all the more, then, is it reckoned as a special day in the Fourth Gospel (Jn 5:10; 7:22-23; 9:14). All characters in the story can tell these times; just as Jesus was socialized to observe Passover by annual pilgrimages (Lk 2:41-42), so too most people would know from synagogue attendance how to reckon these times. While all characters put order into their lives by means of these time markers, this is essentially neutral time in the perspective of the Fourth Gospel; these reckonings of time do little more than serve as a backdrop for the new telling of time articulated by Jesus.

Although days are measured into hours, in John hour is rarely a horological marker, but rather a statement about ideological interpretations of

\footnotetext{
${ }^{1}$ As far back as Aristotle, time was understood as a mental construct rather than an existing thing apart from the mind (Physics 4.10-11).
} 


\section{Telling time in the Fourth Gospel}

time. When Jesus declares that my hour has not yet come (Jn 2:4, 7:30, 8:20), this speaks of God's orchestration of Jesus's life and passion and of Jesus's knowledge of this mystery. The frequent remark about the hour of Jesus's glorification (Jn 12:23; 13:1; 17:1) serves as a marker of Jesus's high status as he begins his return to God and glory. Only insiders reckon his passion as glory and so are able to tell time. Third, hour refers to the period when bad things happen to the disciples (Jn 16:2, 4, 21, 25, 32), that is, markers of phases of their experience. The fact that Jesus foretells this hour indicates that he controls the fate of the disciples and provides an insider interpretation for telling time.

There are misunderstandings between Jesus and His hearers as regards time. For example, his raising the temple of his body in three days contrasts with their estimate of forty-six years to build the temple (Jn 2:19-20). Abraham indeed saw my day, even though Jesus is not yet fifty years (Jn 8:57). Edwards (1994:449-454) argues against those who try to calculate Jesus's age from this remark; he suggests interpreting it according to the week of years in Jubilees 23:10-11, 15.

Jesus's delay of four days allows for the death, burial and corruption of Lazarus, even though this is misunderstood by the disciples (Jn 11:4-16) and by Martha and Mary both of whom complain, If you had been here our brother would not have died (Jn 11:21, 32). When Jesus tells Martha, Your brother will rise again, her reckoning of time does not match that of Jesus, I know he will rise again in the resurrection on the last day (Jn 11:24). Telling time, then, is difficult even for insiders. But these data do not tell us much about the way time is perceived by the Johannine group and how it functions. To enter that realm we need to have recourse to a cultural model of time.

\section{TELLING TIME IN GENERAL}

It is generally accepted that the reckoning of time is a social construct (Leach 1966:124-136; Luckmann, in Bender \& Wellbery 1991:151-166), one which utilizes many potential time markers, such as moon, sun, stars, flood of the Nile, et cetera (Leach 1966:134-135). Nancy Munn, an expert in the anthropology of time, explains precisely what reckoning time means:

Strictly construed, time-reckoning refers to the use of selected cultural categories, or contingent events to tell time - to ask when something happened, will or should happen - and to measure duration to ask how long something takes, or to time it. The relevant 
categories may segment natural processes (including diurnal, solar, and lunar cycles) or human activities into successive intervals.

(Munn 1992:102-103)²

For example, both Genesis 1:3-19 and Plato tells of the basic time markers in the cosmos: darkness/light, sun, moon and stars, which were created to reckon days, months, years and seasons; the seven-day scheme of creation itself produces a week. Many texts indicate an Israelite day to start at sundown and last until the next sundown (Lv 23:32; as well as Gn 1:5, 8, 13, 19). Although other texts present a different calibration (Jdg 19:4-9; $1 \mathrm{Sm}$ 19:11), the sundown-to-sundown model predominated (Stroes 1966:460-475).

Such was the mind and thought of God in the creation of time. The sun and moon and five other stars, which are called the planets, were created by him in order to distinguish and preserve the numbers of time ... and he placed them in the orbits in which the circle of the other was revolving in seven orbits seven stars.

(Plato, Timaeus 38c)

Thus a calendar was born and time was ordered into patterns expressive of the patterns and meanings during which people lived (O'Neil 1975). More precisely, human beings in specific cultural situations use these and other markers to put order into their particular world, in particular the order or rhythm of life embodied in the local agricultural cycle. We see this, for example, in the Gezer calendar (925 BCE):
His two months are (olive) harvest.
His two months are planting (grain). His two months are late planting; His month is hoeing up of flax. His month is harvest of barley. His month is harvest and feasting; His two months are vine-tending. His month is summer fruit.

(ANET, 3rd ed; 320)

Apart from agriculture, we find among the ancients a commonplace scheme on the ages of man, which divide them into various stages:

${ }^{2}$ See Silverman, in Smelser \& Baltes (2001:23) for a classification of time. 


\section{Telling time in the Fourth Gospel}

- Three stages: " ... there were three choirs, corresponding to the three periods of life, which were made up at the festivals, and the choir of old men $(\gamma \epsilon \rho \circ \nu \tau \omega \nu)$ would begin with this song: 'Young valiant men long days ago were we.' Then the choir of men in the prime of life ( $\alpha \kappa \mu \alpha \zeta o \nu \tau \omega \nu)$ would sing in response: 'And that we are: look, if you will and see.' And the third choir, that of the boys ( $\pi \alpha\llcorner\delta \omega \nu)$ would sing: 'And better far 'tis certain we shall be."' (Plutarch, Instituta Laconia 238A-B, cf $1 \mathrm{Jn}$ 2:12-14).

- Four stages: "Twenty years a boy, twenty years a youth, twenty years a young man, twenty years an old man; and these four periods correspond to the four seasons, the boy to spring, the youth to summer, the young man to autumn, and the old man to winter," meaning by youth one not yet grown up and by a young man a man of mature age (Diogenes Laertius, Pythagoras 8.10).

- Augustine lists six ages: infancy (infantia), childhood (pueritia), youth (adulescenti)], young adulthood (juventus), mature adulthood (gravitas), and old age (senectus) (De Genesi contra Manichaeos 1.3541; De Diversis Quaestionibus 58.2; De Vera Religione 26.48).

- Seven stages: "In a man's life there are seven seasons, which they call ages, little boy, boy, land, young man, man, elderly man, old man. He is a little boy until he reaches seven years, the time of the shedding of his teeth; a boy until he reaches puberty, a lad until his chin grows downy, a young man until his body his whole body has grown, an elderly man until fifty-six, and after that an old man" (Solon, cited by Clement of Alexandria, Stromata 6.17). (See also Philo, Creation 103105.)

- or 10 ages (Laporte 1986:278-290).

For example, Aristotle speaks of three ages: "By 'ages' I mean youth ( $\nu \in 0 \tau \eta ́$ ), the prime of life ( $(\dot{\alpha} \kappa \mu \eta \dot{\eta})$, and old age ( $\gamma$ '́ $\rho \alpha \varsigma)$." (Measurements of the human life cycle are often celebrated by rites of passage, which has been an important focus in the study of time (Goody 1958:1-14).) Only the elites and their military had any need to break the night into watches and the day into hours (as early as $2400 \mathrm{BC}$, the twenty-four division of the day derives from the Egyptian practice of counting units of time at night on the basis of the rising of certain 
decanal stars. Presumably for military purposes, the Romans spoke of four vigilae or night watches), calibrating with sundials, water clocks and candles. ${ }^{3}$ The other $98 \%$ of the population had no need for such and so reckoned simply according to moon, sun, stars, wet/dry seasons, as well as the agricultural and birth cycles. ${ }^{4}$ This is what reckoning time is about, although we would suggest that telling time in a group such as that of the Fourth Gospel will be less attuned to time markings and more interested in esoteric or cryptic meanings of time. But for the moment, let us note how the Fourth Gospel reckons time.

We offer at this point 4 classifications for time suggested by anthropological research and by the ancients themselves: past, present, forthcoming, and future; eternal and contingent; sequence and duration; and before and after. We will introduce each classification, indicate its existence in antiquity, and then use it as a lens for reading the Fourth Gospel.

\title{
4. PAST, PRESENT, FORTHCOMING, AND FUTURE
}

This triad seems to have been the most common and important classification of time in antiquity. For example, Plato classified time as past, present and future (Timaeus $37 \mathrm{e}-38 \mathrm{~b}$ ). He contrasted the eternity of the creator of the world with beings which have a past, present and future, thereby using the triad to clarify the difference between what is eternal or contingent:

\begin{abstract}
Was and Shall be are generated forms of Time, although we apply them wrongly, without noticing, to the Eternal Being. For we say that it is or was or will be whereas in truth of speech, is alone is the appropriate term (for God); was and will be on the other hand, are properly applicable to the Becoming which proceeds in Time, since both of these are motions, and it belongs not to that which is ever changeless in its uniformity to become either older or younger through time, nor ever to have become so, nor to be so now, nor to be about to be hereafter (Timaeus 38a).
\end{abstract}

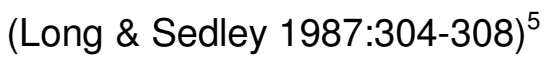

\footnotetext{
${ }^{3}$ On the history of instruments of telling time, see Withrow (1988:21-70), Time in history: Views of time from prehistory to the present day. More technical studies include Winlock (1940), The origin of the ancient Egyptian calendar, and Breasted (1936), Time and its mysteries.

${ }^{4}$ For a comprehensive survey of notions of time and constructions of time from Mediterranean pre-history through classical antiquity, see Whitrow (1988:19-70), Time in history: Views of time from prehistory to the present day.

${ }^{5}$ See Aristotle, Physics 4.10.218a.
} 


\section{Telling time in the Fourth Gospel}

There seems to have been, moreover, continuous discussion of time in Hellenistic philosophy, mostly focusing on the triple classification, past, present, and future (Long \& Sedley 1987:304-308).

As far as the contribution of anthropology to the classification of time, it should be noted that not only do different cultures mean different things by past, present, and future, but they also value them differently in their lives, as noted by Bruce Malina in his presidential address, Christ and time: Swiss or Mediterranean (Malina 1989:1-31). An apt illustration of shifting preferences for one of the triad can be found in a project developed to serve the health needs of the multiple cultures of modern New Mexico among whitch white, native American, Mexican, and colonial Spanish (Kluckhohn \& Strodtbeck 1961:13-15). Their results were subsequently interpreted by John J. Pilch (Pilch \& Malina 2000:1-17), who identifies five values of each of the four cultures noted above: principle mode of human activity, interpersonal relations, time orientation, relationship to nature, and view of human nature. Each topic contained three general options, one of which was emphasized by each of the different culture studied. For our purposes, we need only consider time orientation, which includes past, present and future. To repeat, one of these tends to be dominant in certain cultures, such that we can say that there are future-oriented people, present-oriented, and past-oriented. No culture seems ever to have been exclusively one of these, but to have had a dominant preference for one with a secondary, but minor one for another.

Pilch states that present-oriented people "pay little attention to what has happened in the past and regard the future as both vague and unpredictable" (Pilch \& Malina 2000:14). Past-oriented people, however, include those who revere or worship their ancestors as well as those who have high regard for tradition. Future-oriented people "place an emphasis upon the future - a future which is anticipated to be bigger and better", an attitude that gives them a comparatively high evaluation of change (Pilch \& Malina 2000:14-15). The challenge in Biblical studies arises particularly from the fact that modern Biblical scholars tend to operate within a cultural model that might be termed future-present oriented, whereas Mediterranean peasants generally would have operated within a present-past orientation. To clarify, let us compare past and present-oriented time cultures with futureoriented ones. Preferential future orientation is indicated in the loans taken out for education, for mortgages on homes, for products like automobiles. From the beginning of one's labours, attention is given to social security and to portfolios for retirement. How much delayed gratification is practiced by those who labour to go to college, to do further graduate work, to put off starting a family, to devote time and income to raise children. Conversely, cultures are 
nearly past-less, as many old buildings, houses, significant battle sites, and the like have no value except for present commercial purposes. To repeat, while all have the same three possible classifications for time, not all value each equally. Preferences must be noted.

\subsection{Past, present, forthcoming, and future in antiquity}

To make these insights operational, we need to consider more closely how the ancients understood past, present and future.

\subsubsection{Past}

Past orientation looks back to and relies on a written canon for inspiration and guidance: Homer for the Greeks, the Scriptures for the House of Israel. Pastoriented people value certain mountains or springs or temples because in the past they became sacred in their mythology and maintain that preeminence. Synchronism of the rule of various elites in the past was a common way to telling time; this clearly speaks to past persons and events as valuable:

For fourteen years the thirty-year's truce which had been concluded after the capture of Euboea remained unbroken; but in the fifteenth year, when Chrysis was in the forty-eighth year of her priesthood at Argos, and Aenesias was ephor at Sparta, and Pythodorus had still four months to serve as archon at Athens, in the sixteenth month after the battle of Potidaea, at the opening of spring, some Thebans ...

(Thucydides, History 2.2)

And

In the fifteenth year of the reign of Tiberias Caesar, Pontius Pilate being governor of Judea, and Herod being tetrarch of the region of Ituraea and Trachonitis, and Lysanias tetrarch of Abilene, in the high-priesthood of Annas and Caiaphas, the word of God came to John ...

$(\operatorname{Lk} 3: 1-2)^{6}$

But past events (volcano eruptions, famines, earthquakes) also serve as time markers: "The words of Amos ... in the days of Uzziah, king of Judah, and in the days of Jeroboam the son of Josiah, king of Israel, two years before the earthquake" (Am 1:1). Concern over genealogies likewise indicates the

${ }^{6}$ See also Is 1:1; Jr 1:1-3; 32:1 and Josephus, Ant 18.106. 


\section{Telling time in the Fourth Gospel}

importance of the past, for belonging to an ancient line served as the primary qualification for certain roles and statuses, such as priesthood in Israel. Raymond E Brown (1993:65) illustrates how Biblical genealogies serve different functions. The very interest in ancestry reflects Israel's tribal origins where one's provable identity as a member of the tribe is a passport to survival: the tribe cares for its members. Biblical genealogies are sometimes used to undergird status, especially for offices of king and priest where lineage is important (Ezr 2:62-63; Neh 7:64-65), in other words, where the primary concern is to structure history into epochs and to authenticate a line of (cultic) office holders. The Romans, moreover, were socialized to value the past heroes of their families and to strive to emulate the mos maiorum, masks of the ancestors were kept in the family house and worn at special celebrations. The Romans, then, truly live in the past and under the eyes of others, the key dynamic of an honour-shame society.

\subsubsection{Present}

The meaning of present time in peasant communities is provided by Pierre Bourdieu's study, The attitude of the Algerian peasant toward time (in PittRivers 1963:55-72). For Algerian peasants nothing (was) more foreign than the attempt to secure a hold over the future, and nothing more strange than the idea of an immense and open future as a broad field of innumerable possibilities which man is able to explore and dominate. Bourdieu describes the concept of present that comports with such an outlook, saying, The lapse of time which constitutes the present is the whole of an action seen in the unity of a perception, including both the retained past and the anticipated future. The present of the action embraces, over and above the perceived present, an horizon of the past and of the future tied to the present because the both belong to the same context of meaning (Bourdieu, in Pitt-Rivers 1963:55). Malina (1994:2-5) describes this type of broad present as experienced time.

Because present is understood to encompass so much, the understandings of past and future are pushed outward to apply to more distant and even imaginary times (Bourdieu, in Pitt-Rivers 1963:60). Similarly, times in the remote past can be viewed in terms that are discontinuous with the peasants's world of experience with phrases like, when the animals spoke. Malina (1994:14-15) describes such distant past and future times as imaginary time.

\subsubsection{Forthcoming}

Future often has an important qualification to it. One result of separating the future from the broad experienced present is that another subcategory is required, namely, the forthcoming. The forthcoming, Bourdieu states, is 
perceived in the same manner as the actual present to which it is tied by an organic unity. Potentialities ... are apprehended as incapable of not coming about; since, as they are grasped, they are just as much present as the actual present, directly perceived (Bourdieu, in Pitt-Rivers 1963:61-62). For example, a woman may become pregnant today, but the birth of her baby is not future, but forthcoming, because the fetus is even now present. The same is true of sowing and reaping: the reaping may be months away, but it is not future, rather forthcoming. The cause of the harvest is even now present. A presentoriented view of time, moreover, considers the future very differently from the forthcoming. As Bourdieu (in Pitt-Rivers 1963:62) noted, it is presumptuous to predict; one should also avoid framing projects too far in advance, considering that the act of prediction itself is an act of insolence to God (cf Jas 4:13-15; Lk 12:19-20).

\subsubsection{Future}

Future, while the most dominant category of the triad for modern readers, was comparably neglected by the ancients. By future time we mean the abstract sphere which is outside the horizon of the experienced world. It refers to all the possibilities of what actually does not exist: what can/could, may/might, shall/should, will/would or ought to be (Malina 1996:192). Future differs from present and forthcoming in that it has no causal relationship to what is now occurring or is forthcoming. One may know and infer that a baby will be born if one knows that a woman is pregnant; a harvest is forthcoming (one hopes) since the grain has been sowed. But the future cannot be known, because it is the exclusive domain of God and those to whom God reveals it. It may be utterly discontinuous with the experienced world, since with God all things are possible (Gn 18:14; Jr 32:27; Mt 19:26; Lk 1:37; Rm 4:21). Thus, to paraphrase Malina, cultures with a present-forthcoming orientation set their goals in the present; initiate actions to achieve these goals; thus, they see the forthcoming as continuous with the present. In contrast, future-oriented cultures set goals for the extended or distant future; present activity occurs to achieve remote goals; but there is temporal integration between the distant future with the present (Malina 1996:186).

While it is correct that questions were put to the ancient oracles, it is equally true that the answers were ambiguous and misleading. Knowledge of the future remained out of the grasp of mortals. For example, Plutarch remarks (concerning things indefinitely and groundlessly predicted): "Grant that victory is foretold for a general: he is victorious; or the destruction of the city: it is now overthrown. But (absent from the oracle are not only what shall come to pass, but also how and when and after what and attended by what, 


\section{Telling time in the Fourth Gospel}

that is not a guess" (Oracles at Delphi 399B). In Israel, it was considered blasphemy to try to know what only God knows (see $1 \mathrm{Sm}$ 27:6-14).

Moreover, a passage in Deuteronomy (18:10-11) lists and censures attempts to know the future: diviners, inquirers, soothsayers, augurers, mediums, etc. God alone knows the day on which the sky will crumble, not even Jesus (Mk 13:32); and attempts to pry knowledge of the future out of Jesus are always rebuffed (Ac 1:7).

\subsection{Past, present, forthcoming, and future in the Fourth Gospel}

There is no doubt that past, present and future are important markers of the narrative and indicators of values in the Fourth Gospel. But as we have seen, the emphasis given to each will surely differ from our modern notions of them; one expects to see greater importance given to present and past and very little to future. What meanings, in fact, are given to each? What role does each play in the narrative? Inasmuch as control of time is often of great importance, does Jesus manage time?

\subsubsection{Past}

Since John has Jesus speak this provocative remark about the past, we are attuned to reading Jesus into the past: Before Abraham came into being, "I AM" (Jn 8:58). When Jesus is evaluated as greater than our father Jacob and greater than our father Abraham, the answer is no mere rhetorical synchrisis, but a statement of temporal priority and so superiority. "Abraham saw my day", a remark interpreted as the vision of Abraham at the covenant of the pieces (Gn 15) (Dahl 1976:106-111). "Isaiah saw my day" (Jn 12:41). Jesus's temporal priority to Moses is less clear: "Moses believed in me and so wrote about me" (Jn 5:46), which suggests both temporal and status superiority. Thus, Jesus is portrayed as a figure of Israel's past, who has been active in controlling it.

Pastness has a special value in the ancient world. One thinks of the model of history known as the succession of ages from gold, silver, bronze ... . This degeneration model, found as early as Hesiod's Works and Days (and the vision of the four kingdoms in Dn 2:31-45), became the conceptual norm. ${ }^{7}$

\footnotetext{
${ }^{7}$ Whitrow (1988:46), Time in history: Views of time from prehistory to the present day, provides an intellectual touch to the degenerative model of time: After the fifth century, few, except writers on scientific subjects, had any belief in the idea of progress in the future. Indeed the typical Greek tended to be backward-looking, since the future appeared to him to be the domain of total uncertainty, his only guide being delusive expectation. Even in the sciences it was thought in later antiquity that all wisdom lay in the past. As E R Dodds has remarked: "where men can build their systems only out of used pieces, the notion of progress can have no meaning, the future is devalued in advance" (Dodds, in Wiener 1973:633); in another place Dodds (1973:1-26) noted that along with the dominant degeneration model, there existed an understanding of progress.
} 
While we do not claim that the Fourth Gospel has such a view, it does position Jesus in the ultimate past, that is, in the beginning. And even if he comes (temporally) after John, Jesus was before him, both in regard to time and status. The forthcoming of Jesus is to return to this past by resuming the glory he had with the Father before the world was made (Jn 17:5, 24).

The past, then, speaks to the core of Jesus's identity as a heavenly being who did not come into existence, but who already was in the beginning. He appeared to patriarchs and prophets of Israel's long time past, not only confirming his status as non-created, but also thereby demonstrating superiority to the best of the best and indicating that he is no recent phenomenon, which would imply dubious worth.

\subsubsection{Present}

In the Synoptics Jesus often calls attention to the dominant peasant time value, the present. Today a scripture is fulfilled (Lk 4:21); Today I must dine in your house (Lk 19:5); and Today you will be with me in paradise (Lk 23:43). Although the Greek term for today ( $\sigma \eta^{\prime} \mu \in \rho \nu \nu$ ) appears nowhere in the Fourth Gospel, the document is, nevertheless, focused overwhelmingly on the present, but in strange ways, in particular the various meanings given to now (vûv); we will consider the hour is coming and is now later. Especially at the end of the story, even as Jesus prepares to depart, we find considerable emphasis given to certain experiences and plans by Jesus. now is my soul troubled (Jn 12:27) is certainly a narrower term than today, if only because the continuation looks to God's glory. With Judas's exit, Jesus is now glorified and God is glorified in him (Jn 13:31). But this is hardly an instant in time, but rather an entrance into a time which is totally other, namely, time in God's world. now I go to the Father (Jn 16:5) refers to the entire process of his return to former glory, which seems as much relational as temporal. Although Jesus petitions, Glorify me now with the glory which I had before the world came to be (Jn 17:3), this is hardly a future-oriented request, but a return to the past. Jesus's use of now, then, looks to his passage to the Father and to a present return to past status. Seemingly a temporal word, when used of Jesus now suggests much more than momentary experience, and rather process, yet a process which is not simply temporal.

Friends and enemies are seemingly constrained by now, that is, controlled by time. Peter cannot follow Jesus now, for reasons Jesus knows, but not Peter (Jn 13:36). Jesus reveals now what is soon to happen, so that the disciples will now be strengthened (Jn 14:29, see Jn 16:22). now they know that you have given ... (Jn 17:7), a state of understanding, a duration, not an instant. As regards enemies, now you seek to kill me (Jn 8:40), an 


\section{Telling time in the Fourth Gospel}

action which has been under way for some time. now we know that you have a demon (Jn 8:52), more a conclusion than a time marker. He pulls the veil on hypocrisy when he states, now you say, We see and your sin remains (Jn 9:41). Again, a state of deceit exists for some time which is finally exposed.

\subsubsection{Forthcoming}

Jesus often speaks of events which are the result of processes already under way, but which are not about the distant, disconnected, unknown which has no grounding in the experienced world. Forthcoming events are couched in the following terms: his hour has not come, is coming and is now here; he speaks to crises the disciples will shortly face; most importantly, his transition or return to the Father is imminent, an event grounded in the gospel reports of others trying to kill him and of his being lifted up.

Concerning his hour, Jesus will not solve the wine problem of Cana because my hour has not come (Jn 2:4). This hour seems to function rhetorically in the pattern observed by Giblin (1980:197-211), request, negative reaction, and positive response, a pattern appearing four times: John 2:1-10, 4:46-54, 7:1-8 and 11:5-16. In these four instances Jesus does not respond to requests until he is in control of the situation. These requests are all challenges to Jesus, which a typical honour-conscious male must resist. ${ }^{8}$ He does not act until it pleases him; and they cannot kill him until it suits Jesus and God (Jn 2:4; 11:5-16). Jesus, then, controls time and his hour, moreover, looks to forthcoming, not future events of his passage to God (Jn 12:23; 13:1; 17:1). Jesus controls time on his terms, and only he can tell time.

But hour also indicates that affairs are in transition or that events will shortly happen which prove Jesus's control of time. Concerning worship, the hour is coming and is now here when God will be worshiped in truth and spirit (Jn 4:21, 23) a transition from worship in a fixed sacred space. A claim is made that the hour is coming and is here when Jesus will call the dead from their tombs $(5: 25)$, of which Lazarus is immediate the proof.

Concerning the disciples, three things are said: the hour is coming when they will be expelled and even killed (Jn 16:1-2), scattered (Jn 16:32), and not spoken to in figures (Jn 16:25).

Jesus informs them of imminent crises, which indicates that he has knowledge of what is forthcoming; and his speech attempts to exercise some control over it. The pattern is repetitive: I tell you about something which is forthcoming for the very purpose that when it occurs, you may believe, ... to keep from stumbling $\ldots$ to have peace (Jn 13:19, 14:29, 16:1, 4, 15:11). We

\footnotetext{
${ }^{8}$ Giblin's observation about the form of the four passages is profitably enlarged when one knows the ubiquitous challenge-riposte exchange (Neyrey 2006:65-76, 193-194).
} 
interpret these five remarks as speaking about what is forthcoming, not about the future. The events anticipated are rooted in their experienced world and are considered as the summations of events already under way (Neyrey 2006:265-266).

\subsubsection{Future}

Unlike forthcoming, future refers to time outside the experienced world; there is no causal relationship between the present and what will occur; unlike the present, the future is unknown and unknowable, unless it is revealed. As in the Synoptics there is little reference to the future. All references to the future cluster around Jesus's executive or eschatological power. The apology in John 5:19-29 argues that Jesus has God's two foundational powers: creative power, hence he works even on the sabbath, as does God, and eschatological power, which includes power to call the dead from their tombs, to raise them and judge them, to have (eternal) life in himself, to lay down his life and take it again (Jn 10:17-18). ${ }^{9}$ Taking 5:21-29 as a compendium of information about the eschatological power of Jesus, we can see this claim to future power unfolding in Jesus's subsequent remarks about the future. First, he will call the dead from their tombs and raise them for judgment (Jn 5:2729), an event whose time is unknowable, but will occur in the ages to come. Jesus offers bread from heaven which has a present effect, namely, eternal life; nevertheless he will raise them on the last day (Jn 6:39, 44, 54; 11:24)

Characters in the Fourth Gospel look forward to an imaginary future marked off by certain features that are discontinuous with the present. For example, the woman at the well looks forward to a future time when religious mysteries will be solved, described as when he (Messiah) comes (Jn 4:25). Likewise, the crowds of Jerusalem face a challenge to their present, experienced time when they say, "When the Christ comes, He will not perform more signs than this man has, will He?" (Jn 7:31). Similarly, Martha says of the still dead Lazarus, "I know that he will rise again in the resurrection on the last day" (Jn 10:24).

\section{ETERNAL AND CONTINGENT TIME}

\subsection{Eternal and contingent time in antiquity}

Philo, who was acutely sensitive to avoid using anthropomorphisms in connection with God, contrasted God's time with that of the created world.

\footnotetext{
${ }^{9}$ A full discussion of the eschatological power of Jesus is found in Neyrey (1988:25-35, 52-58, 87-91).
} 


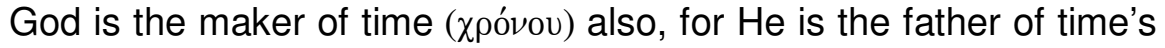
father, that is of the universe, and has caused the movements of the one to be the source of the generation of the other. Thus time stands to God in relation to a grandson ... And thus with God there is no future, since He has made the boundaries of the ages subject

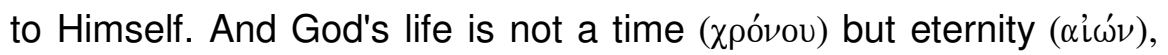
which is the archetype and pattern of time; and in eternity there is no past nor future, but only present existence.

(Philo, Unchangeableness 31-32) $^{10}$

Likewise, Philo balanced his commitments to both Genesis and Plato's Timaeus by reading the Genesis account of creation as accommodating language so as to avoid the notion of the creator acting within time. Important for us, however, is to notice the patterning of building on Exodus 3:14, I am who I am, as expressing the eternity of the deity. Philo frequently uses the abbreviation of this as a name for God (Moses 1.75; Dreams 1.231; Change 11; Abraham 121). Implied in I am is the sense of uncreated existence in the past and imperishable in the future. Turning more directly to the Hellenistic world, we note a distinction made between a true deity and a divinized moral. True gods had no beginning or end; mortals indeed come into being and die very un-godlike experiences, but are then made eternal (Neyrey 1991:448450). A suitable example of this thinking is found in Diodor of Sicily:

As regards the gods, men of ancient times have handed down two different conceptions. Certain gods are eternal and imperishable ... for each of these genesis and duration are from everlasting to everlasting. But the other gods were terrestrial beings who attained to immortal honors and fame because of their benefactions to mankind (6.1.2). ${ }^{11}$

Moreover, the same theology of God's eternity is evident in Hellenistic Jewish writings, such as the Apocalypse of Abraham: Eternal One, Mighty One, Holy El, God autocrat, self-originate, incorruptible, immaculate, unbegotten,

\footnotetext{
${ }^{10}$ And in another place he makes the same point: "He goes on to say - thereby heightening the glory of the child to be - that he will be born 'in another year' (Gn xii.21). And by other year he does not mean an interval of time which is measured by the revolutions of sin and moon, but something truly mysterious, strange and new, other than the realm of sight and sense, having its place in the realm of the incorporeal and intelligible, and to it belongs the model and archetype of time, eternity and aeon. The world aeon (á) $\left.\omega^{\prime} v\right)$ signifies the life of the world of thought, as time (Xpóvos) is the life of the perceptible" (Philo, Change 267).

${ }^{11}$ Plutarch provides another example of this distinction: My native tradition removes this god from among those deities who were changed from mortals into immortals. Like Heracles and Dionysus, whose virtues enabled them to cast off mortality and suffering; but he is one of those deities who are unbegotten and eternal (Pelopidas 16).
} 
spotless, immortal, self-perfected, self-devised, without mother, without father, ungenerated (Jn 17:8-11).

Furthermore, by using a wide variety of terms for past, present and future eternity, ancient writers acknowledged true gods to be those without creation or beginning, without birth, mother, father or genealogy and without end, without death, without corruption (Neyrey 1991:440-447). They pass away, but he remains forever (Heb 7:3) (Dodds 1963:51). Finally, both Israelite and Hellenistic god-talk speaks of the deity as the One who is, who was and is to come. The expressions of this in Isiah 41:1 and Revelation 1:4, 8 and 4:8 are quite similar to confessions of Zeus or Isis as who is, who was, and who is to come.

\subsection{Eternal and contingent time in the Fourth Gospel}

In the Fourth Gospel, we presume that all characters in the narrative were born and died, although Jesus is a special case. They all came into being and had a beginning, and they all went out of being and so ended. But Abraham, who indeed fits this pattern, is made to play the foil to Jesus in the conflict in John 8:51-58. Jesus stated that If anyone keeps my word he will never see death (Jn 8:51). The audience misunderstands and mocks Jesus: Abraham died, as did the prophets; and you say If any one keeps my words he will never taste death (Jn 8:52). Despite the rumors about the Beloved Disciple in 21:23, we find no place where Jesus ever claimed that his disciples would not die. Returning to Abraham. of him Jesus claims that Abraham saw my day, not in the sense of a prophecy to be fulfilled, but in a theophany such as the one at the Covenant of the Pieces (Gn 15). The argument is not that Abraham had no beginning or ending or that a disciple will be immortal. On the contrary; the focus is on Jesus as the eternally existing I AM.

The reader knows that Jesus is uncreated, and in fact was with God in the beginning before anything was made (Jn 1:1-3). And after his sojourn here, Jesus will return to the glory which I had with You before the world began (Jn 17:5). Along the way we were told that Jesus has power from God to lay down my life and power to take it up (Jn 10:17-18). At a minimum, readers must think that Jesus is no mere mortal; he enjoys eternal duration because he had no beginning in the past and will have no ending in the future. This sense of heavenly time is best expressed in the appropriation by Jesus of the of the divine name I am who I am spoken to Moses (Ex 3:14). Instances of this are widespread, in the LXX translations (Is 43:25; $51: 12 ; 52: 6$ ), in Philo (Change 11; Worse 160; Dreams 1.230-31; Moses 1.66; 74-76), and in the targums to Exodus 3:14 (Neyrey 1988:213-220). Hence, when Jesus declares that before Abraham came into being, I AM (Jn 8:58), several thing are being 


\section{Telling time in the Fourth Gospel}

said about his eternity. First, using the fact that Abraham is a figure of the remote past, Jesus claims that, Abraham was born, Jesus already existed. But the use of I AM is unlike the triad that God was, is and will be, for it excludes all past time; I AM means continually existing, having no beginning, being uncreated. Moreover, there are other instances in the use of I AM's which confirm this. Earlier in John 8 we find two uses of I AM, which are juxtaposed with death. In John 8:23-24, Jesus established the fact that he and they live in two contrasting worlds: "You are from below, I am from above; you are of this world, I am not of this world." And those below and of this world who cannot acknowledge that Jesus is from above and not of this world will die; this death is not merely the death all mortals taste, but a death which will endure and for which there will be no life hereafter. The antidote for this death is to accept Jesus as a figure from above and not of this world, that is, to believe that I AM.

Jesus's existence is that of a heavenly figure, unlike those who will die in their sins, he exists eternally. Comparably, in John 8:28 Jesus juxtaposes death and eternal existence. Utilizing their death plots against him (Jn 7:1, 19$20,25)$, Jesus disguises these death threats in his use of a metaphor of honour and exaltation, lifted up. As the plot continues, Jesus will indeed be executed, although he dies according to the power of God given him (Jn 10:17). It is curious that lift (i.e, death) is linked with I AM. Should not death put the lie to I AM, being without end? The double meaning of lift is well know, but only to insiders. To outsiders it means crucifixion and shame; but to insiders it means not the destruction of Jesus, but of his return to the presence of the eternal God (Jn 1:18, 13:1-3) and his return to glory (Jn 17:5). Unlike any other person on earth, he has divine power to take his life back. No, death does not cancel out the eternal existence of I AM.

\section{SEQUENCE AND DURATION}

As Goody noted, the experience of time takes two major forms: sequence and duration. From the standpoint of sequence, events are seen as located in a particular order along a moving continuum. The experience of duration derives from the relative span of events and of intervals within them (Goody, in Sills 1986:31).

\subsection{Sequence and duration in antiquity}

Illustrative of sequence would be the ancient sense of stages of a man's life. As we saw above, some divided the duration of a life span into three or four or seven or ten stages. The agricultural year begins with planting and ends with harvesting (Jn 4:36-37), the duration of which might be eight or nine 
months. The calendar of worship also provides a sequence; for example, in Israel there was a regular sequence of fast days and shekel dues; weekly, monthly, and annual feast days; pilgrimage feasts; festival and mid-festival days; and other holy days (Herr, in Safrai \& Stern 1976:834-864). Some are based on agriculture (Tabernacles, Pentecost), while others commemorate of historical events (Passover, Hanukkah). A feast might last a week, but with a climactic final day (Jn 7:37-38).

Duration describes the years and months of exile from Athens, Rome or Jerusalem and of occupation by an imperial army. It refers to the time during which one is influenced by a certain constellation of the zodiac (Malina 1995:12-18, 52-61). Length of time in the army may determine one's rank:

\begin{abstract}
After electing the consuls, they appoint military tribunes, fourteen from those who have seen five year's service and ten from those who have seen ten. As for the rest, a cavalry soldier must serve for ten years in all and an infantry solider for sixteen years before reaching the age of forty-six. No one is eligible for any political office before he has completed ten year's service.
\end{abstract}

(Polybius, Histories 6.19.1-5)

\title{
6.2 Sequence and duration in the Fourth Gospel
}

The evangelist knows about the particular order of many things, such as the sequencing of feasts (Tabernacles, Passover, Dedication) and the triple keeping of Passover by Jesus. He knows of the sequencing of days of the week, with emphasis on the Sabbath. Some feasts, he knows, last a week. All life cycles have a sequencing from coming into being to dying (Jn 8:52-58). The sequence for Jesus, however, is most unusual. Mary is evidently his mother she gave birth to him; but Jesus has a heavenly Father from whom he came into the world and to whose lap he will return. What scholars call his parabola descent and ascent effectively outlines the sequence of his pitching his tent and folding his tent. It has a definite duration in contrast to the indefinite duration as part of the heavenly world. Similarly, his termination, i.e, his death, is in fact a return, a lifting up, and a return to glory. Hence, Jesus's sequence markers clash with those of his audience and the characters in the narrative.

In contrast, duration is a significant label in the interpretation of the Fourth Gospel. It is often said that Jesus, his disciples and others remained. As regards Jesus himself, the Spirit of God remained on him (Jn 1:32-33), signaling a prolonged relationship with God, in contrast with all others who receive the Spirit. Theirs is passing, whereas on Jesus the Spirit remained. This suggests both duration and status. Jesus, moreover, is wont to remain in 


\section{Telling time in the Fourth Gospel}

some place for a time, either two days (Jn 2:12; 4:40) or more (Jn 11:6). He also remains in places of safety, apart from trial and capture (Jn 7:9; 10:40; 11:54), which signals control of time and so, status. The most significant block of material on remaining occurs in the Farewell Address where it proves necessary to affirm close social relations, despite Jesus's departure. Jesus the broker, even in his transition, affirms the patron-broker relationship between God-Father, who is patron, and disciples, who are clients. On the one hand, the relationship of God and Jesus is secure, as Jesus asserts, "I am in the Father and the Father in me. The words I say to you, I do not speak on my own, but the Father who dwells $\left(\mu \epsilon^{\prime} \nu \omega \nu\right)$ in me. Believe me that I am in the Father and the Father in me" (Jn 14:10-11). Conversely, the relationship between Jesus as broker and the disciples as clients is likewise secure on the condition that they remain in Jesus, the vine: "Abide in me, and I in you ... unless it abides in the vine ... unless you abide in me ... He who abides in me, and $I$ in him, he it is that bears much fruit ... If a man does not abide in me, he is cast forth as a branch and withers ... If you abide in me, and my words abide in you, ask whatever you will, and it shall be done for you" (Jn 15:4-7). In the same vein, the disciples are exhorted to keep something so as to remain: "Remain in my love. If you keep my commandments, you will abide in my love, just as I have kept my Father's commandments and abide in his love" (Jn 15:9-10). It is also possible that God's anger might remain on some (Jn 3:36) and that sin remains in wilfully blind people (Jn 9:41); finally, the slave son does not remain in the house (Jn 8:35), only the true son.

Remaining, then, embraces character as well.

The author, as we can see, focuses on duration, not in general but specifically in terms of Jesus's premier relationships, God and the disciples. The actual days that he remained here or there seem only to indicate the degree of acceptance he experienced, not chronological periods. One might extrapolate that this emphasis in the use of remain has something to do with the relationships within the community, as opposed to the society surrounding it. Loyalty and fidelity are premier virtues in the Jesus group, distinguishing them from drop-outs (Jn 6:66). As regards sequence, Jesus indeed spends time in this world (three Passovers), but his timing is ambiguous, for there is scant interest in a particular order of events.

\section{BEFORE AND AFTER}

\subsection{Before and after in antiquity.}

For Aristotle, who treats this classification in two places (Metaphysics 5.11; Physics 4.11), before and after embraces space, time, movement, power and arrangement. The terms prior (before) and posterior (after) are applied to 
some things, on the assumption that there is a first, i.e, a beginning, in each class. For example: place, some things are prior in place (because closer to some place determined by nature) and posterior (because further); time, some things are prior in time (the Trojan war is prior to the Persian, because further away) and posterior (by being nearer to the present, i.e., in the case of future events); movement, some stage is prior (the boy is prior to the man); arrangement, things placed at intervals in reference to one definite thing (in a chorus, the second man is prior to the third) (Coope 2005:60-81).

We may say that someone is before us either in precedence or in time; a brother may be both, firstborn and heir. The same is true of after, for someone may stand behind us in precedence or in time. Before and after, nevertheless, are considered significant time markers in the ancient world. Aristotle observed that we apprehend time only when we have marked motion, marking it by befores or afters. When we perceive a before and an after, then we say that there is time. For time is just this number of motion in respect to befores and afters. ${ }^{12}$

\subsection{Before and after in the Fourth Gospel.}

We must ask two questions:

- What cultural meanings might be given in antiquity to events which were before or were after?

- Is there any relationship between first and last and before and after? Before, on the one hand, can have both temporal and status meaning, as in the chronological relationship between John and Jesus. He who comes after me ranks before me, for he was before me (Jn 1:15, 30). In one sense, John appears prior to/before Jesus, who is temporally posterior/comes after John. But, John, as does Jesus, speaks in riddles. To the uninitiated eye, John's appearance before Jesus is true and not true; even John calibrates Jesus's time by an esoteric criterion: "for he was before me". In human telling of time, Jesus is younger than John, but John tells time differently in that Jesus was absolutely before John came into being, i.e, was born. The reason, Jesus was $\pi \rho \hat{\omega} \tau$, (Dodd 1963:273-274) In fact, then, Jesus is prior to John both in time and in status, but only for those who have ears to hear.

${ }^{12}$ Aristotle, Physics 4.11.219a.22-24 and 219b.1-2. 


\section{Telling time in the Fourth Gospel}

Although there is no other occurrence of the pair before and after, there are many terms for before as a temporal marker which are worth noting. First, $\pi \rho o ́$ is used frequently as a sequence indicator of the events of the narrative: "Before Philip called you ... I saw you" (Jn 1:48); the cripple man has no one to bring him before another goes ( $\mathrm{Jn} 5: 7$ ); the Passover is a familiar time marker: before the Passover (Jn 11:55); six days before the feast (Jn 21:1) and before the feast (Jn 13:1). Nothing special here. But when Jesus says Before ( $\pi \rho i v)$ Abraham came into being, I AM (Jn 8:58), here Jesus claims to be uniquely before or prior in both time and precedence. After all, Jesus is greater than our father Abraham (Jn 8:53) in time and status. Third, there are times when Jesus gives warning about forthcoming perils, so that having alerted the disciples before they happen, they will be prepared: now I have told you before it takes place, so that when it takes place you will believe ( $\mathrm{Jn}$ 14:29; see also Jn 13:19; 14:25; 16:1, 4). Whereas prophets deliver their oracles about forthcoming events on the basis of God's authority ("Thus says the Lord ..."), Jesus speaks on his own and so displays a type of control of time.

Finally, in Jesus's prayer he speaks about "the glory which I had with you before the world was made" (Jn 17:5). Inasmuch as creation is the condition for as well as the beginning of time, Jesus claims to be ultimately prior. Beside time, this remark speaks of his rank and status: "Glorify me with glory I had ...." suggests return to highest status, a return to being face-to-face with God (Jn 1:1) and to the Father's lap (Jn 1:18). Similarly, he speaks again of "glory which you have given me before the foundation of the world" (Jn 17:24). Like John 17:5, this before differs qualitatively from all other before because it is the absolute and ultimate before, for it is in the beginning ( $\mathrm{Jn}$ 1:1). Hence, Jesus's remarks about glory before the world was made acclaim him to be before all creation in time and prior to all in status. Needless to say, such a telling of time would either be unknowable by outsiders or cause for their rage.

\section{SUMMARY AND FURTHER QUESTIONS}

\subsection{What we now know}

8.1.1 Telling time is a rich, significant, and necessary element in the narrative and in the interpretation of the characters of the Fourth Gospel. There is much more to time in the Fourth Gospel than consideration of hour and day. 
8.1.2 Materials from cultural anthropology provide cross-cultural concepts and terminology for interpreting time as used by the peoples of the classical world, especially in light of the realization that time is a social construct.

8.1.3 By means of cultural studies we identified many classifications of time, selecting only four for examination here.

8.1.4 The aptness of those four classifications was confirmed repeatedly by reference to materials from the Greco-Roman world. Thus, their presence and use in classical writings warrants applying them to still another document from the classical world, namely, the Fourth Gospel.

8.1.5 The four classifications prove to be significant tools for gathering data in the gospel concerning telling time, and for interpreting it.

8.1.6 The contribution of cultural studies of time, then, facilitates a fresh reading of the Fourth Gospel in four ways:

- the attention to data in the document, which is ordinarily not noticed or treated as of minor significance;

- consideration of Jesus's character in terms of the control he exercises over time;

- the curious phenomenon that no character, either inside or outside, understands time as Jesus tells it;

- $\quad$ and a special understanding of the role and status of Jesus as a timeless figure and even a figure whose time resembles that of God: uncreated, non-contingent, eternally existing I AM.

\subsection{Conclusions from the classifications used}

Although many cultures employ the classification past, present, forthcoming, and future, the meanings given to each are often highly specific and idiosyncratic to their respective groups. And the same is true of the Fourth Gospel. Jesus' past serves to promote him as an extraordinary figure. His past argues that: he is greater than any patriarch because he was and was operating vis-à-vis the patriarchs in ancient times, and his past is eternally existing, since he already was in the beginning. Furthermore, unlike presentoriented Israelites, Jesus especially operates out of forthcoming time, which emerges as the premier category of time in the Fourth Gospel. In regard to the character of Jesus, he himself has knowledge of all that is forthcoming (his hour has come; crisis for the disciples; his leaving), which illustrates his 


\section{Telling time in the Fourth Gospel}

control of time, a property thought to belongs only to God. Future, the undeveloped part of this classification in the Fourth Gospel, seems to apply only to Jesus's eschatological power to raise the dead.

Jesus, then, is a figure with a past which embraces both in the beginning and existing in the past significant role and status markers and without a past inasmuch as he is eternally existing. He knows all that is forthcoming indicating super-human control of events, and who will in the future will raise the dead, a unique power given him by God. But no character grasps this, for it is consistently misunderstood and even rejected.

The classification eternal vs contingent functions to distinguish Jesus (from above and not of the world) from all other persons (from below, of this world) again a significant character marker. Jesus's time is eternal, in that he had no beginning and is responsible as creator for all contingent beings, who are born and necessarily die. Non-contingent or eternal time belongs only to I AM, who existed before Abraham came into being and subsequently died. Jesus, by virtue of the command given him by God (Jn 10:17-18), lays down his life and takes it back again. This classification, then, speaks to Jesus's character as a figure beyond contingent being; as one who controls time; and as one who shares the time of God. In this case, contingent beings grasp the claims implied by Jesus as indicative of his heavenly role and status, but they reject them and try to prove him wrong by their endless attempts to kill him. He alone knows when his hour has come, and so he exercises control of all situations, all times.

The sequencing of events is of minor importance in comparison with duration. But duration speaks primarily to the relationships Jesus enjoys with God, Spirit and disciples. On the one hand, God's spirit remains on Jesus (Jn 1:32-33), an indication of maximum approval; on the other, Jesus remains in contexts favorable to him. Enduring relationships, moreover, become a dominant theme in John 13-17: Jesus and the disciples (Jn 15:1-9); Jesus and the Father (Jn 14:10-11); and Jesus, the Father and the disciples (Jn 14:20, 23). This speaks to Jesus's role as broker or agent in the Fourth Gospel (Neyrey 2007:271-291), whereby This, of course, could only be understood by insiders, and so it represents esoteric information revealed the few but concealed from many again a matter of control.

The fourth classification (before vs after) likewise speaks to relationships of status as well as temporality. John's remarks about Jesus (Jn $1: 15,30$ ), who comes after John but has priority to him, replicate the noncontingent time of Jesus. He was before being born of a woman; and he is prior in status as well. Similarly, before Abraham came into being, Jesus already existed (Jn 5:56, 58) and enjoyed status priority. Thus before speaks 
to the uniqueness of Jesus's character as one who enjoys eternal time, whose past time relates him more to the world of God than that of the disciples. This knowledge seems to be understood by some (John and disciples), but resisted by many.

\subsection{Further inquiry}

There are many more classifications of time, such as ordinary and special, beginning and ending, night and day, time and space, static vs dynamic,and cyclical vs linear. Two classifications in particular deserve further attention.

\subsubsection{Special vs ordinary}

This classification has been known as the distinction made between $\chi \rho o ́ v o \varsigma$

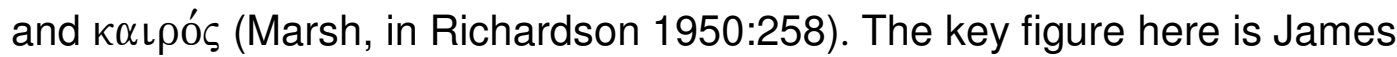
Barr (1962) who criticized the view that $\kappa \alpha \iota \rho$ ó $\varsigma$ refers to important experienced time, whereas $\chi \rho o ́ \nu o \varsigma$ was flat, undifferentiated chronological time. He

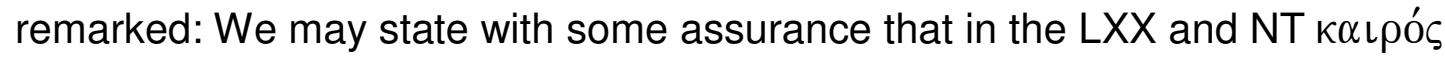
keeps the special meaning, in which it shows opposition to $\chi \rho o ́ \nu o s$, of right time, only in certain contexts; and that over a large area of the usage ... two

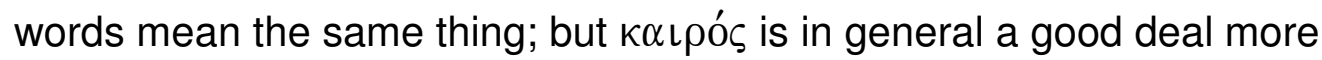
frequent (Barr 1962:42). ${ }^{13}$

Both terms appear in the Fourth Gospel. Jesus rejects the urging of his brothers to travel to the feast of Tabernacles. He will not go, but they can because your time ( $\kappa \propto\llcorner\rho o ́ \varsigma)$ is always, ordinary and without significance (Jn

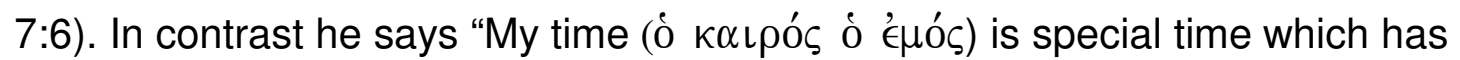
not yet come." The world does not hate them (no special time for their expulsion or death), but it hates Jesus, who protects himself until it is his time.

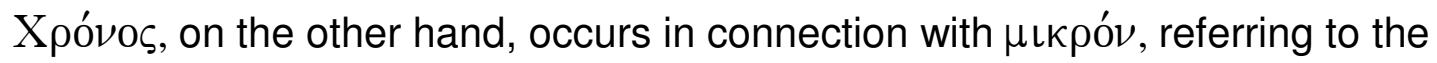
brief time left for outsiders to walk in the light (Jn 12:35), but mostly to the brief moments Jesus is still with the disciples (Jn 13:33) and the brief intervals between his death and return (Jn 14:19, 16:16-18). Thus special time contrasts Jesus's hour, his forthcoming death and his time with the disciples with ordinary time, which describes persons who belong to this world and who are not hated by it. Jesus controls time here and obscures his meaning.

\footnotetext{
${ }^{13}$ An important voice on the distinction between special and ordinary time is that of Quintilian: Time may be understood in two different senses, general and special (generaliter, specialiter). The first sense is seen in words and phrases such as now, formerly, in the days of Alexander, in the days of the siege of Troy. The second sense occurs when we speak either of definite periods of time, such as in summer, in winter, by day, by day, or of fortuitous periods such as in time of pestilence, in time of war, during a banquets Certain Latin writers have thought it sufficient distinction to call the general sense time's (tempus) and the special times's (tempora) (Inst Orat 5.10.42-43).
} 


\section{Telling time in the Fourth Gospel}

\subsubsection{Beginning and ending}

In one sense we are returning to the classification eternal vs contingent time. It belongs to the philosopher's god to be Eternal and imperishable, whose genesis and duration are from everlasting to everlasting (Diodor of Sicily 6.1.2); or, ingenerable and undestructable (Diogenes Laertius, Zeno 7.137) or unbegotten and eternal (Plutarch, Pelopidas 16). An important variation of this is the declaration that God has no beginning and no ending. An important voice on the distinction between special and ordinary time is that of Quintilian: Time may be understood in two different senses, general and special (generaliter, specialiter). The first sense is seen in words and phrases such as now, formerly, in the days of Alexander, in the days of the siege of Troy. The second sense occurs when we speak either of definite periods of time, such as in summer, in winter, by day, by day, or of fortuitous periods such as in time of pestilence, in time of war, during a banquets Certain Latin writers have thought it sufficient distinction to call the general sense time's (tempus) and the special times's (tempora) (Inst Orat 5.10.42-43).

This should help understand what kind of time the author is telling when he says that "In the beginning was the word ... he was in the beginning with God" (Jn 1:1-2). He is before creation (Jn 17:5, 24), hence he must be uncreated and un-begotten. Comparably, Jesus has no end of existence, for as he told us earlier, as the Father has life in himself, so he have given the Son to have life in himself (Jn 5:26), which must be seen in connection with the command he has from the Father: "I have power to lay down my life and I have power to take it back" (Jn 10:17-18). Contingent begins have endings, but not eternal ones. Moreover, the narrative of the events of John 18-19 is not told as an ending, but as a return to the beginning, namely Jesus's transit to heaven, God and his own former glory. Jesus departs this world for that of God (Jn 13:1); he goes to God (Jn 16:17), is lifted up (Jn 3:14, 8:28, 12:32), and ascends back there ( $\mathrm{Jn} 3: 13,20: 17)$. These are not endings, but returns. Far from being subject to death which means an end, he has power over death, that of others and his own. He will raise the dead and requite them. This classification speaks to Jesus's absolute control of time, as all persons and things begin and end or are born and die. This also reflects upon Jesus himself, who has no beginning or ending, and so belongs in the heavenly world. Mostly characters in the narrative do not understand what is said about Jesus, as they labour continually to reduce him to a status of a being who was born and will die. 


\subsection{Time, secrecy and gnosis}

We have noted continually that Jesus's audienceinsiders and outsidersnever understands his remarks about time. Moreover, the Fourth Gospel tells us that most of Jesus's remarks were difficult, if not impossible, to understand. Why is this so? On the literary level, the gospel is replete with instances of the pattern statement, misunderstanding, clarification (Neyrey 1988:42-44). For example, Jesus tells Martha that Lazarus will arise, which she takes to mean the final time when the dead are raised; Jesus means the very present time, as he makes his way to Lazarus's tomb. Why employ this pattern over and over and with insiders as well as outsiders? In addition, the Fourth Gospel is filled with double-meaning words (Leroy 1968; Carson 1982:61-91; Richard 1985:96112), riddles (Thatcher 2006), irony (Duke 1985) and other practices of protecting a gnosis (Neyrey 2006:9-15). While such literary features are commonly found in ancient literature, why so many in the Fourth Gospel? And to what purpose? We can only provide at this point clues to were to find materials to investigate these questions. In general we urge readers to consult studies on secrecy in antiquity, a very common phenomenon (Neyrey, in Segovia 1998:79-109; Avery-Peck, Harrington \& Neusner 2004:199-230). No one knew all things at any given time, and what one knows is in index of status within a group. Thus secrets about time are always kept from outsiders, but are gradually revealed to insiders. Secrecy, moreover, speaks to role and status: Jesus, a heavenly person in control of time, reveals secrets bit-by-bit to insiders, but conceals them from outsiders. Secrecy, then, functions to showcase Jesus as both revealer and concealer. Only those born of spirit can understand Jesus's spirit message, but those born of earth are condemned to know only earthly things.

Finally, recent scholarship has introduced to New Testament scholars the phenomenon of antilanguage. It is accepted that the community of the Fourth Gospel was a sect or an antisociety. A group thus alien to all his neighbours speaks differently from them, for in their position as an antisociety, they speak antilanguage. We are responsible to Michael A K Halliday (1978) for the primary research on this phenomenon, whose materials were subsequently used to interpret the Fourth Gospel by Bruce J Malina (1994:167-182). ${ }^{77}$ Antilanguage is a way in which isolated and harassed groups keep their secrets from those hostile to them. When speaking to an outsider, one's meaning and intent are purposely hidden for the speaker uses language that outsiders will hear and recognize but which is not the meaning

\footnotetext{
${ }^{14}$ This material serves as one of the important tools for the interpretation of the whole Gospel (see the commentary on the Fourth Gospel by Malina \& Rohrbaugh 1998:4-14).
} 


\section{Telling time in the Fourth Gospel}

given to the discourse by the speaker. Malina and Rohrbaugh present of list of terms of double meaning: gangs in Omaha use words like bent, but mean that one belongs to a gang; a frog is not an aquatic critter but a girl of low moral standards who will jump in any car (Malina \& Rohrbaugh 1998:8-9). Of use to this inquiry, antilanguage is speech intended to hide meaning or to confuse others. It is a defensive strategy of a group surrounded and harrassed by enemies. It operates on the premise that group members know the code, but outsiders do not. Obviously there is no effort to enlighten outsiders.

\section{Works consulted}

Avery-Peck, A, Harrington, D \& Neusner, J (eds) 2004. When Judaism and Christianity began. Leiden: Brill.

Barr, J 1962. Biblical words for time. Naperville, IL: Alex Allenson.

Barret, C K 1978. The Gospel according to St John. Philadelphia, PA: Westminster. Beck, R 2007. A brief history of ancient astrology. Oxford: Blackwell.

Bender, J \& Wellbery, D (eds) 1991. Chronotypes: The construction of time. Stanford, CA: Stanford University Press.

Breasted, $\mathrm{J} \mathrm{H}$ 1936. The beginning of time-measurement and the origins of our calendar, in Time and its mysteries, Series I. New York: New York University Press.

Brown, R E 1966. The Gospel according to John. New York: Doubleday.

Brown, R A 1993. The birth of the Messiah. New York: Doubleday

Busada, C 2003. Calendar and theology: An investigation into a possible mutable calendrical system in the Fourth Gospel. PhD dissertation, Southeastern Baptist Theological Seminary.

Carson, D A 1982. Understanding misunderstandings in the Fourth Gospel. TynBul 33, 61-91.

Coope, U 2005. Time for Aristotle, Physica IV.10-14. Oxford: Clarendon.

Culpepper, R A 1983. Anatomy of the Fourth Gospel: A study in literary design. Philadelphia, PA: Fortress.

Cumont, F 1912. Astrology and religion among the Greeks and the Romans. New York: Putnam.

Dahl, N A 1976. The Johannine church and history: Jesus in the memory of the Early Church. Minneapolis, MN: Augsburg.

Davies, M 1992. Rhetoric and reference in the Fourth Gospel. Sheffield: JSOT. (JSNT Sup.)

Dodd, C H 1963. Historical tradition in the Fourth Gospel. Cambridge: Cambridge University Press.

Dodds, E. R 1963. Proclus: The elements of theology. Oxford: Clarendon.

Dodds, E R 1973. The ancient concept of progress. Oxford: Oxford University Press.

Duke, P 1985. Irony in the Fourth Gospel. Atlanta, GA: Society of Biblical Literature.

Edwards, M J 1994. Not yet fifty years old. NTS 40, 449-454.

Gell, A 1992. The anthropology of time: Cultural constructions of temporal maps and images. Oxford: Berg Publishers.

Giblin, $\mathrm{CH}$ 2006. Suggestion, negative response, and positive action in St John's portrayal of Jesus. NTS 26, 197-211. 
Goody, J (ed) 1958. The developmental cycle in domestic groups. Cambridge:

Cambridge University Press.

Goody, J 1968. Time: Social organization. IESS 16, 31-41.

Gosden, C 1994. Social being and time. Oxford: Blackwell.

Hall, E T 1959. The silent language. Greenwich, CT: Fawcett.

Halliday, M A K 1978. Language as social semiotic: The social interpretation of language and meaning. Baltimore, MD: University Park Press.

Johnson, M D 1969. The purpose of the Biblical genealogies with special reference to the setting of the genealogies of Jesus. Cambridge: Cambridge University Press.

Keener, C S 2003. The Gospel of John: A commentary, Vol 1. Peabody, MA: Hendrickson.

Kluckhohn, F R \& Strodtbeck, F L 1961. Variations in value orientations. Evanston, IL: Row \& Peterson.

Laporte, J 1986. The ages of life in Philo of Alexandria. SBLSP, 278-290.

Lauer, R H 1981. Temporal man: The meaning and uses of social time. New York: Praeger.

Leach, E R 1966. Rethinking anthropology, revised edition. Oxford: Berg Publishers.

Leroy, H 1968. Rätsel und Missverständnis: Ein Beitrag sur Formgeschichte des Johannesevangelium. Bonn: Hanstein.

Long, A A \& Sedley, D N 1987. The Hellenistic philosophers, Vol 1: Translations of the principle sources with philosophical commentary. Cambridge: Cambridge University Press.

Malina, B J 1984. The Gospel of John in sociolinguistic perspective. Berkeley, CA: Center for Hermeneutical Studies.

Malina, B J 1989. Christ and time: Swiss or Mediterranean? CBQ 51, 1-31.

Malina, B J 1994. John's: The Maverick Christian Group: The evidence of Sociolinguistics. BTB 24, 167-82.

Malina, B J 1995. On the genre and message of Revelation: Star visions and sky journeys. Peabody, MA: Hendrickson.

Malina, B J 1996. The social world of Jesus and the Gospels. London: Routledge.

Malina, B J \& Rohrbaugh, R L 1998. Social-science commentary on the Gospel of John. Minneapolis, MN: Fortress.

Munn, N D 1992. The cultural anthropology of time: A critical essay. Annual Review of Anthropology 21, 102-103.

Neyrey, J H 1988. An ideology of revolt: John's Christology in social-science perspective. Philadelphia, PA: Fortress.

Neyrey, J H 1991. "Without beginning of days or end of Life" (Hebrews 7:3): Topos for a true deity. CBQ 53, 448-50.

Neyrey, J H 2006. The Gospel of John. Cambridge: Cambridge University Press.

Neyrey, J H 2007. I am the door's (Jn 10:7, 9): Jesus the broker in the Fourth Gospel. CBQ 69, 271-291.

O'Neil, W M 1975. Time and the calendars. Sydney: Sydney University Press.

Pilch, J J \& Malina, B (eds) 1998. Handbook of Biblical social values. Peabody, MA: Hendrickson.

Pilch, J J 2000. Healing in the New Testament. Minneapolis, MN: Fortress.

Pitt-Rivers, J (ed) 1963. Mediterranean countrymen: Essays in the social anthropology of the Mediterranean. Paris: Mouton. 


\section{Telling time in the Fourth Gospel}

Richard, E 1985. Expressions of double meaning and their function in the Gospel of John. NTS 31, 96-112.

Richardson, A (ed) 1950. A theological word book of the Bible. London: Macmillan.

Safrai, S \& Stern, M 1976. The Jewish people in the first century, Vol 2. Philadelphia, PA: Fortress.

Salvoni, F 1963. Nevertheless, My hour has not yet come. ResQ 7, 236-41.

Segovia, F (ed) 1998. What is John? Vol II: Literary and social readings of the Fourth Gospel. Atlanta, GA: Scholars.

Sills, D L (ed) 1968. The international encyclopaedia of the social sciences, Vol 16. New York: Macmillan \& The Free Press.

Smelser, N J \& Baltes, P P 2001. The cultural anthropology of time: A critical essay, Annual Review of Anthropology 21. Amsterdam: Elsevier.

Stroes, H R 1966. Does the day begin in the evening or the morning. VT 16, 460-75.

Thatcher, T 2006. Jesus the riddler: The power of ambiguity in the Gospel. Louisville, $\mathrm{KY}$ : Westminster John Knox.

Tiemersma, D \& Oosterling, H A F (eds) 1996. Time and temporality in cultural perspective. Amsterdam: Rodopi.

Walker, B P 1978. The meaning and significance of the seventh hour's in John 4:52. Studia Biblica 255-263.

Walker, N 1960. The reckoning of hours in the Fourth Gospel. NovT 4, 69-73.

Whitrow, G J 1988. Time in history. Oxford: Oxford University Press.

Wiener, P P 1973. Dictionary of the history of Ideas. New York: Scribner.

Wilson, R R 1977. Genealogy and history in the Biblical world. New Haven, CT: Yale University Press.

Winlock, H E 1940. The origin of the ancient Egyptian calendar, Proc. Amaer. Phil. Society 83.

Wright, R A (ed) 1984. African philosophy: An introduction. Lanham, MD: University Press of America. 